\title{
Increased vaginal pH in Ugandan women: what does it indicate?
}

\author{
G. G. G. Donders ${ }^{1,2,3}$ - A. Gonzaga ${ }^{4}$ - C. Marconi ${ }^{5}$ - F. Donders ${ }^{1,6}$ • T. Michiels ${ }^{1,6}$ • \\ N. Eggermont ${ }^{7}$ - G. Bellen ${ }^{1}$ - J. Lule ${ }^{4}$. J. Byamughisa ${ }^{4}$
}

Received: 23 January 2016 / Accepted: 25 April 2016 /Published online: 14 May 2016

(C) Springer-Verlag Berlin Heidelberg 2016

\begin{abstract}
Abnormal vaginal flora (AVF), indicative of bacterial vaginosis $(\mathrm{BV})$ and/or aerobic vaginitis (AV), amongst other abnormalities, is a risk factor for multiple complications in pregnant as well as non-pregnant women. Screening for such conditions could help prevent these complications. Can self-testing for increased vaginal $\mathrm{pH}$ reliably detect $\mathrm{BV}$ and other high-risk microflora types, and is this more accurate than performing Gram stain-based Nugent score when screening for high-risk microflora? A total of 344 women presenting at different outpatient clinics in Mulago Hospital and Mbuikwe Outpatient clinics in Kampala, Uganda, were asked to test themselves by introducing a gloved finger into the vagina and smearing it on a microscopy slide, on which a $\mathrm{pH}$ strip was attached. Self-assessed categories of normal ( $\mathrm{pH} 3.6-$ 4.4), intermediate (4.5-4.7) or high $\mathrm{pH}(>4.7)$ were compared with demographic and with centralised microscopic data, both in air-dried rehydrated wet mounts (Femicare), as well as in Gram-stained specimens (Nugent). AVF was present in $38 \%$,
\end{abstract}

G. G. G. Donders

gilbert.donders@femicare.net

1 Femicare vzw, Clinical Research for Women, Gasthuismolenstraat 31, 3300 Tienen, Belgium

2 Department of Obstetrics and Gynecology, Antwerp University Hospital, Edegem, Belgium

3 Department of Obstetrics and Gynecology, General Hospital H Hart, Tienen, Belgium

4 Department of Obstetrics and Gynecology, Mulago University Hospital, Kampala, Uganda

5 Department of Pathology, Botucatu Medical School, UNESP_-Universidade Estadual Paulista, Botucatu, Brazil

6 MS, Faculty of Medicine, University of Leuven, Leuven, Belgium

7 MS, Faculty of Medicine, Ghent University, Ghent, Belgium
$\mathrm{BV}$ in $25 \%$ and $\mathrm{AV}$ in $11 \%$ of patients. High $\mathrm{pH}$ and $\mathrm{AVF}$ is correlated with human immunodeficiency virus (HIV), infertility, frequent sex, but not vaginal douching. Screening for raised $\mathrm{pH}$ detects $90 \%$ of AVF cases, but would require testing over half of the population. As AV and non-infectious conditions are frequent in women with AVF and high $\mathrm{pH}$, Nugent score alone is an insufficient technique to screen women for a high-risk vaginal microflora, especially in infertile and HIV-infected women.

\section{Introduction}

Bacterial vaginosis (BV) is a pathologic condition of the vagina, caused by an overgrowth of anaerobic bacteria, leading to a bothersome foul smelling discharge. Increased $\mathrm{pH}$ is one of the Amsel criteria to diagnose the disease and is often used as a surrogate marker for the presence of BV [1-4]. However, it needs to be taken into consideration that $\mathrm{pH}$ can also be increased by other factors, both infectious (e.g. chlamydia, gonorrhoea, trichomoniasis, aerobic vaginitis) [5] and noninfectious (e.g. sperm, vaginal douching, use of creams etc.). Former studies suggested a high specificity of increased $\mathrm{pH}$ for predicting $\mathrm{BV}$ in a population with a low risk of infectious lower genital tract abnormalities [1] and can be used to prevent preterm birth [6], but in high-risk populations, it has never been properly addressed.

Besides BV, another abnormal infectious condition of the vagina, aerobic vaginitis (AV), is often associated with a disrupted flora, but without the typical granular microflora displayed by anaerobes in BV flora [7]. As opposed to BV, a more scanty flora of cocci or small enteric bacilli is present in $\mathrm{AV}$, as well as a variable inflammatory response, as demonstrated by increased numbers of leucocytes, presence of toxic leukocytes and high concentrations of pro-inflammatory 
cytokines in the vaginal fluid [8]. The presence of an abnormal vaginal flora (AVF), $\mathrm{AV}$ and $\mathrm{BV}$ increases the risk of morbidity in both pregnant and non-pregnant women [9].

Black women seem to be more vulnerable to AVF and BV than Caucasian women [10], both in the US [11] and in African countries [12], with alleged prevalence rates of over $50 \%[11,12]$. In a former paper, we reported high acceptance and feasibility of vaginal $\mathrm{pH}$ self-screening of Ugandan women [13]. In the present paper, we address the question as to whether such vaginal $\mathrm{pH}$ measurement is a surrogate marker for $\mathrm{BV}$, or also relates to other important, non-BV abnormalities of the vaginal microenvironment.

\section{Materials and methods}

\begin{abstract}
Aim
To determine which proportion of women with abnormal vaginal $\mathrm{pH}$ in Uganda has microscopical confirmed BV. How important are flora types other than full-blown BV, like AV and partial BV, in these women?
\end{abstract}

\section{Subjects}

Inclusion of 360 unselected, consecutive and consenting women between 18 and 50 years of age, living in rural areas, semi-urban areas or urban areas, and presenting at birth control, general gynaecology, infertility and prenatal clinics at Mulago/Mbuikwe Hospital outpatient departments.. The study and informed consent document was approved by the ethical committee of the Mulago University Hospital and all patients approved and signed an informed consent before entering the study.

After having read and signed the informed consent, women were asked to examine themselves with a sterile glove by introducing one finger into the vagina and spreading the obtained vaginal fluid on a glass slide, on which a $\mathrm{pH}$ strip $(\mathrm{pH}-$ Fix, range pH 3.6-6.1, Macherey-Nagel GmbH \& Co. KG, Düren, Germany) was fixed, as described and demonstrated elsewhere [14]. After $1 \mathrm{~min}$, the patients had to interpret the $\mathrm{pH}$ strip result as: (1) normal (yellow, corresponding to a $\mathrm{pH}$ range of 3.6-4.4), (2) intermediate (orange, corresponding to a $\mathrm{pH}$ range of 4.4-4.7) or (3) abnormal (red, corresponding to a $\mathrm{pH}$ range of more than 4.7). The slide was kept for later transportation to Femicare, clinical centre for research for women in Tienen, Belgium, where microscopy was performed after rehydration with normal saline by a blinded investigator [15] and for Gram staining and scoring according to Nugent [16].

With the assistance of a registered nurse, a questionnaire was filled out to collect information on age, medical history, obstetrical history and sexual health of the participating women. Participating women were offered a small transportation fee of 5 Euros.

\section{Laboratory testing}

The slides were transported to a central microscopy laboratory (Femicare, Tienen, Belgium) for microscopy reading of rehydrated air-dried smears. A $400 \times$ magnification Leica IM1000 phase contrast light microscope (Leica, Marburg, Germany) was used, and various were recorded, as outlined in the following sections. The validated microscopic findings [lactobacillary grade (LBG), BV, AV] were linked to the three $\mathrm{pH}$ groups, normal, intermediate and abnormal, as described above.

\section{$L B G$}

Normal, grade I flora, corresponds to predominantly lactobacillary morphotypes, with very few coccoid bacteria present [care being taken not to misidentify the cellular debris from lysed epithelial cells (epitheliolysis) as coccoid bacteria]. The intermediate grade II flora corresponds to a diminished lactobacillary flora, mixed with other bacteria. We subdivided this group into slightly disturbed, fairly normal (IIa) and moderately disturbed, rather abnormal (IIb) lactobacillary flora [7, 17]. Finally, the grossly abnormal grade III flora consists of numerous other bacteria, with no lactobacilli present. LBG 0 is a state where no flora is discovered, so, also, no lactobacillary morphotypes can be seen, nor other microflora. As both LBG IIb and LBG III are considered abnormal (e.g. in pregnancy), both were considered together with LBG 0 as AVF in the definition of outcome parameters. It is important to stress that not all cases with AVF equal BV. Several other abnormalities can be associated with AVF, such as complicated candidosis, trichomoniasis and AV [7].

\section{BV types}

$\mathrm{BV}$ is diagnosed as the presence of Gardnerella or Mobiluncus morphotypes and/or clue cells, in combination with the absence of lactobacilli (lactobacillary grade III). Full-blown BV is defined as a full replacement of the lactobacillary flora with typical granular, anaerobic morphotypes of bacteria, resulting in $>20 \%$ clue cells, while partial BV indicates a transition form, with patchy granular $\mathrm{BV}$ areas and areas with normal or AV flora in the same slide [7]. This results in sporadic clue cells, accounting for less than $20 \%$ of epithelial cells. The former diagnosis equates with a Nugent score $>6$ on Gram stains; the Nugent equivalent of the latter is unknown, as their intermediate flora does not completely cover this diagnosis. Due to their particular and diverse pathogenicity, both partial BV and full-blown BV are withheld as outcome parameters in the outcome analysis. 
Indeed, during pregnancy, partial BV seemed to be more frequently related to preterm delivery than full-blown BV, indicating that the presence of these non-aerobic bacterial areas may play an important role in the causation of preterm birth $[18,19]$.

\section{AV score}

The diagnosis of AV is also purely based on microscopy. Lactobacillary grades are the basis for a composite score (AV score) to which any of the four following variables are added: leucocytes, presence of toxic leucocytes, presence of parabasal cells and background flora [8]. A composite score $\leq 2$ represents normality. A score of 3 to 4 corresponds to slight $\mathrm{AV}$, a score above 6 (to a maximum of 10) to severe AV. A score of 8 to 10 is similar to the so-called 'desquamative inflammatory vaginitis,' so that the latter diagnosis can be seen as the most extreme form of AV. Moderate and severe $\mathrm{AV}$ ( AV score $>4$ ) and severe AV (AV score $>6$ ) were considered clinically significant outcome parameters in the analysis.

\section{Confounding factors}

As possible confounding factors, we also searched for the presence of red blood cells and sperm on the smears. Red blood cells were not discovered, since women were not allowed to participate when they have any sign of menstrual or other bleeding. Sperm was recognised as typical ovaloidshaped bodies, with a clear acrosomal cap in darker shade, and with or without the presence of tails [7]. Presence of sperm was marked as a non-quantitative, bimodal marker (present or absent).

Lastly, slides were also stained according to Gram's method and scored according to the Nugent scoring system [16]. In this system, a Nugent score of 1 to 3 is considered normal, 4 to 6 intermediate and 7-10 compatible with BV.

\section{Statistical analysis}

Discrete numerical values were expressed as proportions and compared by the use of Chi-square tests or Fisher's test in case of numbers lower than 5 expected values in any particular cell. For multiple columns, the analysis of variance (ANOVA) test was used. Continuous variables, after confirming normal distribution, were tested with Student's t-test. $p$-Values $<0.05$ were considered significant and $<0.01$ highly significant. For sensitivity and specificity analysis of the $\mathrm{pH}$ as a screening test, a Nugent score of 7-10 was used as the gold standard, as the classical Amsel criteria contain $\mathrm{pH}$ itself as a composite criterion.

\section{Results}

Of the 360 women, the data from 344 (95.6\%) could be analysed. Of the remaining 16, the questionnaire was not properly filled out, a self-assessment of vaginal $\mathrm{pH}$ was not possible, the vaginal smear was lost or the slide was broken. Vaginal wet mount and Gram stain was possible for the slides of 338 women $(93.9 \%)$. The epidemiologic characteristics of the study group are given in Table 1 . The mean age of the women was $28.3 \pm 6.0$ years, parity ranged from 0 to 7 (mean $2.0)$ and educational level was low: only $92(26.7 \%)$ attended school until the age of 18 years or above. The proportion of women with abnormal vaginal $\mathrm{pH}$ did not differ with the level of education. Most women lived in urban regions or in the vicinity of a big city, 87/336 (25.9\%) living in the countryside; their $\mathrm{pH}$ patterns did not differ according to the living area, nor to the tribes from which they originated (detailed data on file).

Of the whole group, 144 (41.9\%) women attended antenatal, 30 (8.7\%) gynaecology, 18 (5.2\%) infertility and 147 (42.7\%) family planning clinics. Most women attending either the gynaecology or the antenatal clinic had a low $\mathrm{pH}$ (43.3\% and $42.4 \%$, respectively), while $20 \%$ of women expressed a high $\mathrm{pH}$ above 4.7 . This was in contrast with the low proportion of women with low $\mathrm{pH}$ in the family planning clinic $(21.8 \%)$ or infertility clinic (5.6\%) (33/165 vs. $74 /$ $174, p<0.0001)$. In the family planning clinic, $75 / 147$ $(51.0 \%)$ women had an intermediate $\mathrm{pH}$ of $4.5-4.7$, compared to $52 / 144(36.1 \%)$ in the antenatal group $(p<0.01)$ and $11 / 30(36.7 \%)$ in the gynaecology group $(p=0.1)$. In the infertility group, $10 / 18(55.6 \%)$ patients had a high vaginal $\mathrm{pH}$ of $>4.7$, compared to $77 / 323(23.8 \%)$ in the other groups $(p=0.0027)$.

Age of sexual debut did not influence the vaginal $\mathrm{pH}$, but the number of previous sexual partners did: $45 / 147$ (30.6\%) of women with three or more partners had high vaginal $\mathrm{pH}$, compared to $44 / 193(22.8 \%)$ women with less than three lifetime partners $(p=0.039)$.

Since the only $p$-values below 0.1 were found within the groups presenting on different consultations (prenatal vs. gynaecology, infertility or family planning), multivariate analysis was not considered appropriate.

As shown in Fig. 1, self-assessed vaginal $\mathrm{pH}$ correlated very well with the wet mount findings lactobacillary grade (AVF, scores 1-4) and the AV (1-10) and BV scores (1-3). Similarly, self-measured $\mathrm{pH}$ also correlated very well with the mean Nugent score on Gram-stained specimens: the Nugent score was $1.14 \pm 2.1$ for $\mathrm{pH}<4.4,3.5 \pm 3.6$ for $\mathrm{pH} 4.5-4.7$ and $5.2 \pm 3.3$ for $\mathrm{pH}>4.7(p<0.0001$, Table 2$)$.

The prevalence of AVF was 146/338 (43.2\%), ranging from $15.1 \%$ in women with low $\mathrm{pH}$ to $45.5 \%$ in women with intermediate $\mathrm{pH}$ and $77.0 \%$ in women with high $\mathrm{pH}$ (Table 2). BV (Nugent 7-10) was present in 84/338 (24.9 \%) women, 
Table 1 Demographics of the 344 Ugandan women with normal, intermediate and elevated vaginal pH. Complete data on age and tribe region were missing for five women. The partner was present at the consultation in only four women $(0.8 \%)$

\begin{tabular}{|c|c|c|c|c|}
\hline & $\mathrm{pH}<4.4, n=107$ & $\mathrm{pH} 4.5-4.7, n=145$ & $\mathrm{pH}>4.7, n=87$ & $p$-Value \\
\hline $\mathrm{Age}^{\mathrm{a}}$ & $27.53 \pm 5.31, n=101$ & $28.72 \pm 6.13, n=137$ & $28.51 \pm 6.64, n=83$ & 0.9 \\
\hline Parity & $1.86 \pm 1.65, n=105$ & $2.1 \pm 1.59, n=144$ & $2.14 \pm 1.73, n=87$ & 0.4 \\
\hline Tribe region & $n=107$ & $n=145$ & $n=87$ & \\
\hline Central & 50 & 68 & 52 & 0.1 \\
\hline East & 11 & 14 & 5 & 0.5 \\
\hline West & 17 & 25 & 6 & 0.09 \\
\hline South & 4 & 3 & 2 & 0.7 \\
\hline North & 6 & 14 & 5 & 0.4 \\
\hline Other & 19 & 21 & 17 & 0.8 \\
\hline Educational level & $n=106$ & $n=145$ & $n=86$ & \\
\hline$<6$ years & $5(4.7 \%)$ & $3(2.0 \%)$ & $4(4.6 \%)$ & 0.5 \\
\hline $6-12$ years & $20(18.9 \%)$ & $34(23.4 \%)$ & $24(27.9 \%)$ & \\
\hline $12-18$ years & $50(47.2 \%)$ & $65(44.8 \%)$ & $40(46.5 \%)$ & \\
\hline$>18$ years & $31(29.2 \%)$ & $43(29.6 \%)$ & $18(20.9 \%)$ & \\
\hline Region & $n=106$ & $n=144$ & $n=86$ & \\
\hline Rural & $23(21.7 \%)$ & $40(27.8 \%)$ & $24(27.9 \%)$ & 0.8 \\
\hline Semi-urban & $43(40.6 \%)$ & $51(35.4 \%)$ & $30(34.9 \%)$ & \\
\hline Urban & $40(37.7 \%)$ & $53(36.8 \%)$ & $32(37.2 \%)$ & \\
\hline HIV-positive & 9/104 (8.7\%) & $20 / 139(14.4 \%)$ & $11 / 84(13.1 \%)$ & $0.039^{\mathrm{c}}$ \\
\hline Age when having first child & $20.2 \pm 4.29, n=83$ & $20.0 \pm 3.83, n=123$ & $19.6 \pm 4.69, n=71$ & 0.9 \\
\hline Age when first had sex & $17.79 \pm 3.13, n=104$ & $17.76 \pm 2.79, n=142$ & $16.92 \pm 2.91, n=85$ & 0.9 \\
\hline Visited traditional healer & $10(9.4 \%), n=106$ & $10(6.9 \%), n=144$ & $6(6.9 \%), n=87$ & 0.5 \\
\hline Previous lifetime sexual partners & $n=106$ & $n=145$ & $n=89$ & \\
\hline Less than 3 & $69(65.1 \%)$ & $80(55.2 \%)$ & $44(49.4 \%)$ & $0.039^{\mathrm{b}}$ \\
\hline 3 or more & $37(34.9 \%)$ & $65(44.8 \%)$ & $45(50.5 \%)$ & \\
\hline Vaginal douching during last 2 months ${ }^{\mathrm{d}}$ & $n=106$ & $n=145$ & $n=87$ & $0.15^{\mathrm{b}}$ \\
\hline$>1 /$ day & $76(71.7 \%)$ & $107(73.8 \%)$ & $72(82.8 \%)$ & 0.3 \\
\hline Infrequent & $10(9.4 \%)$ & $16(11.0 \%)$ & $2(2.2 \%)$ & 0.3 \\
\hline Never & $20(18.9 \%)$ & $22(15.2 \%)$ & $13(14.9 \%)$ & Ref. \\
\hline Contraception & $n=107$ & $n=145$ & $n=87$ & \\
\hline No contraceptive $e^{e}$ & $32(29.9 \%)$ & $57(39.3 \%)$ & $32(36.8 \%)$ & Ref. \\
\hline Pill & $3(2.8 \%)$ & $6(4.1 \%)$ & $5(1.1 \%)$ & - \\
\hline Condoms & $7(6.5 \%)$ & $10(6.9 \%)$ & $3(3.4 \%)$ & 0.3 \\
\hline Copper IUD & $3(2.8 \%)$ & $2(1.4 \%)$ & $3(3.4 \%)$ & - \\
\hline Hormonal IUD & 0 & $1(0.7 \%)$ & 0 & - \\
\hline Depo-Provera injection & $5(4.7 \%)$ & $12(8.3 \%)$ & $9(10.3 \%)$ & 0.8 \\
\hline Norplant & $3(2.8 \%)$ & $3(2 \%)$ & 0 & \\
\hline Collection group & $n=107$ & $n=145$ & $n=87$ & \\
\hline Antenatal & $61(57.0 \%)$ & $52(35.9 \%)$ & $31(35.6 \%)$ & Ref. \\
\hline Family planning & $32(29.9 \%)$ & $75(51.7 \%)$ & $40(46.0 \%)$ & 0.0027 \\
\hline Infertility & $1(0.9 \%)$ & $7(4.8 \%)$ & $10(11.5 \%)$ & 0.01 \\
\hline Gynaecology & $13(12.1 \%)$ & $11(7.6 \%)$ & $6(6.9 \%)$ & Ref \\
\hline
\end{tabular}

${ }^{a}$ Twenty-three women did not know their exact age or did not want to disclose

${ }^{\mathrm{b}}$ Chi-square for trend

${ }^{\mathrm{c}} \mathrm{Chi}^{2}$ for $\mathrm{pH}<4.4$ versus $\mathrm{pH} \geq 4.5$

${ }^{\mathrm{d}}$ Infrequent vaginal douching was reported as follows: once/day $(n=9)$; few times/week $(n=5)$; once/week $(n=8)$; now and then $(n=3)$; only after menses $(n=3)$; none, due to no partner

${ }^{\mathrm{e}}$ Reasons for no contraception: none, want to become pregnant; none, due to other reason; calendar method; temperature method; coitus interruptus; sterilisation woman/man

corresponding well with the number of BV women diagnosed by the wet mount technique [84/338, of which $63 / 338$ (18.6 \%) had full-blown BV and 21/338 (6.2\%) partial BV]. Full-blown BV was found in $34.5 \%$ of women with $\mathrm{pH}$ above 4.7 and in $3.8 \%$ of women with $\mathrm{pH}<4.5(p<0.001)$. Partial $\mathrm{BV}$ was found with an almost equal likelihood in the group with $\mathrm{pH} 4.5-4.7(7.5 \%)$ as in the group with $\mathrm{pH}$ above 7.7
(8.1\%), which is higher than in the low $\mathrm{pH}(\mathrm{pH}<4.5)$ group $\left(2.8 \%, p=0.08, p_{\text {trend }}=0.03\right)$. This was different from the prevalence of intermediate flora on Gram stains, which was similar in all $\mathrm{pH}$ groups.

Compared to Nugent $7-10$ as the gold standard, the sensitivity (Se) of increased $\mathrm{pH}(\mathrm{pH} \geq 4.5)$ was $95.2 \%(80 / 84)$ and the specificity (Sp) was $40.6 \%$ (103/254). The negative 
Mean microscopy score according to vaginal $\mathrm{pH}$

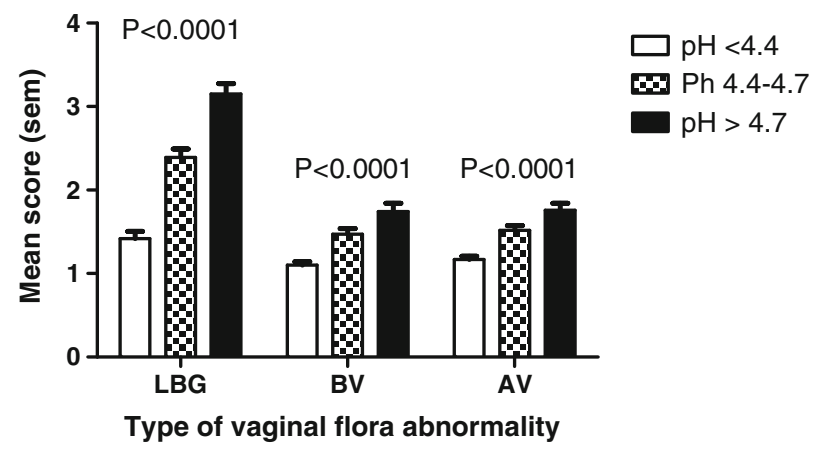

Fig. 1 Relation of self-measured vaginal $\mathrm{pH}$ with microscopic flora abnormalities in 338 unselected Ugandan women

(NPV) and positive (PPV) predictive values were $96.3 \%$ $(103 / 107)$ and $34.6 \%(80 / 231)$, respectively, indicating a high false-positive test rate of $65.4 \%$. If a pH cut-off of 4.7 was chosen, the Se was $45.2 \%(38 / 84)$, Sp $81.7 \%(205 / 254)$, NPV 81.7 \% (205/251) and PPV $43.6 \%$ (38/87), still implicating a high false-positive rate of $56.3 \%$.

Moderate AV was present in 38/338 (11.2\%) and severe AV in 11/338 (3.3\%). Most cases of severe AV were present in the elevated $\mathrm{pH}$ group: $9.2 \%$ in $\mathrm{pH}>4.7,2 \%$ in the intermediate $\mathrm{pH}$ group and none in the low $\mathrm{pH}$ group of $\mathrm{pH}<4.5(p<0.001)$. For moderate to severe $\mathrm{AV}$, a similar trend is seen with high $\mathrm{pH}: 17.2 \%, 7.6 \%$ and $0.9 \% \mathrm{AV}$ presence in high, moderate an low $\mathrm{pH}$ groups, respectively $(p<0.001)$.

If $\mathrm{pH}$ above 4.4 was to be used as a method of selection for further screening, $87.3 \%$ of AVF, $91.7 \%$ of BV and $96.3 \%$ of $\mathrm{AV}$ would have been discovered. On the other hand, this type of screening would require that about two-thirds of women would have to be screened (68.6\%) in order to detect about $90 \%$ of abnormalities. Increasing the threshold to $\mathrm{pH}>4.7$ would lower the sensitivity and detect only $50.7 \%$ of AVF, $44.0 \%$ of BV and $55.6 \%$ of AV.
As a potential confounding factor, the presence of sperm was analysed. In the group with $\mathrm{pH}<4.5$, sperm was detected in 10/106 (9.4\%) women, in the group with $\mathrm{pH} 4.5-4.7$ in 20 / $148(13.5 \%)$ women and in the group with high $\mathrm{pH}$ above 4.7 in 16/93 (15.4\%) women. Although a trend was noted, the difference between groups was not significant (Chi-square for trend: $2.4, p=0.1$ ).

\section{Discussion}

In low-resource countries with a high prevalence of all the above medical conditions, screening and treating AVF and BV could be an advantageous and cost-beneficial approach. In order to be successful, such a screening test has to be widely accessible, affordable, easy to perform, accepted by the target population and efficacious. AVF, especially BV, is a particular risk factor for adverse outcome in pregnant women, and for acquiring sexually transmitted infections (STIs) in nonpregnant women. Screening for such abnormalities is of major relevance in high-risk populations.

Because of its simplicity, accessibility and low cost, selftesting for vaginal $\mathrm{pH}$ indicator strip could be the most ideal substitute test for high-risk flora. Over $85 \%$ of Ugandan women were keen on testing themselves, did not find it distressing or difficult to understand and HIV-positive patients were even more motivated [13]. In the present study, we tested the relevance of this method.

We found a strong correlation between self-measured $\mathrm{pH}$ and the severity score of AVF, BV and AV. The rates of AV $(11.2 \%)$ and $\mathrm{BV}(24.8 \%)$ flora together roughly accounted for almost all cases of AVF (37.1 \%). Although the vast majority of women with $\mathrm{pH}$ above 4.7 had AVF on microscopy, only $43 \%$ of them had BV. If the cut-off was set at a $\mathrm{pH}$ of 4.5 , $56 \%$ had AVF and $37.5 \%$ had BV. With this lower cut-off, the specificity of finding BV was also very low: only roughly 4
Table 2 Correlation of selfassessed $\mathrm{pH}$ with rehydrated wet mount microscopy (AVF, BV, $\mathrm{AV})$ and Gram stain findings (Nugent) in 338 Ugandan women presenting at different gynaecology units in Malao University Hospital in Kampala

\begin{tabular}{lllll}
\hline Vaginal pH by self-assessment & $\mathrm{pH}<4.4, n=106$ & $\mathrm{pH} 4.5-4.7, n=145$ & $\mathrm{pH}>4.7, n=87$ & $p$-Value \\
\hline Rehydrated wet mount & & & & \\
AVF (LBG 0-IIb-III) & $16(15.1 \%)$ & $66(45.5 \%)$ & $64(77.0 \%)$ & $<0.001$ \\
Partial BV & $3(2.8 \%)$ & $11(7.5 \%)$ & $7(8.1 \%)$ & $<0.03$ \\
Full BV & $4(3.8 \%)$ & $29(20 \%)$ & $30(34.5 \%)$ & $<0.001$ \\
AV score $>6$ & 0 & $3(2.0 \%)$ & $8(9.2 \%)$ & $<0.001$ \\
AV score $>4$ & $1(0.9 \%)$ & $11(7.6 \%)$ & $15(17.2 \%)$ & $<0.001$ \\
Gram stain & & & & \\
Nugent 1-3 (Nl) & $91(85.0 \%)$ & $84(58.3 \%)$ & $33(37.9 \%)$ & $<0.001$ \\
Nugent 4-6 (IM) & $12(11.2 \%)$ & $18(12.5 \%)$ & $16(18.4 \%)$ & 0.3 \\
Nugent 7-10 (BV) & $4(3.7 \%)$ & $42(29.2 \%)$ & $38(43.7 \%)$ & $<0.001$ \\
Mean Nugent score & $1.14 \pm 2.12$ & $3.46 \pm 3.58$ & $5.23 \pm 3.32$ & \\
\hline
\end{tabular}

AVF: abnormal vaginal flora; LBG: lactobacillary grades; BV: bacterial vaginosis; AV: aerobic vaginitis; Nl: normal flora; IM: intermediate flora (Nugent) 
out of 10 of women indeed had BV (Nugent 7-10), indicating a false-positive rate as high as $65 \%$. Increasing the cut-off to a $\mathrm{pH}$ above 4.7 , this specificity rose to $82 \%$, but at the expense of a poor sensitivity of $45 \%$, and still a high false-positive rate of $56 \%$. In other words, in this central African society, the finding of an increased $\mathrm{pH}$ is indicative of $\mathrm{BV}$ in only less than half of the cases.

So, not only are there reasons other than AVF to cause increased vaginal $\mathrm{pH}$ in Ugandan women (especially in the group with borderline $\mathrm{pH}$ elevations), but, also, BV is clearly not the only infectious abnormality that causes AVF and increased $\mathrm{pH}$. Of other abnormalities, AV contributes an important part. Like BV, AV is an important risk factor in pregnancy $[18,19]$. Also, outside pregnancy, studies indicate that $\mathrm{AV}$ is more prevalent than originally thought [20], and may be a risk factor for worsening cervical dysplasia [21] and acquisition of STIs in sex workers [22, 23]. As awareness for this condition is increasing, new therapies are being tested [24-27] and more data on its prevalence and pathogenicity will become available over time.

The positive predictive value of $\mathrm{pH} \geq 4.5$ to detect AVF of $53 \%$ indicates that increased $\mathrm{pH}$ may point to conditions other than $\mathrm{BV}$ or $\mathrm{AV}$, such as frequent or recent sexual intercourse. Although we did not ask for the frequency or timing of intercourse, we discovered a direct relation between the number of lifetime sexual partners and vaginal $\mathrm{pH}$, and a trend was seen towards increased presence of sperm in the group with higher $\mathrm{pH}$. In this population, most women perform vaginal douching, the majority even on a daily basis. Whether this practise is responsible for the high prevalence of AVF and increased vaginal $\mathrm{pH}$ is not certain and, in this study, we could not discover any relation between the frequency of douching and the vaginal $\mathrm{pH}$. Neither was age, parity, tribal origin, area of living, use of contraception or level of education associated with increased $\mathrm{pH}$.

HIV-positive women were more likely to have an increased $\mathrm{pH}$, which fits with the fact that AVF and BV are risk factors for acquiring HIV, especially if women also engage in highrisk sexual behaviour [28]. Remarkably, women seeking advice in a fertility clinic or in a family planning unit were at higher risk for having abnormal vaginal $\mathrm{pH}$ as compared to women attending general gynaecology or antenatal clinics. As $\mathrm{BV}$ becomes less frequent and the $\mathrm{pH}$ progressively decreases as pregnancy advances [29], it may explain the higher rate of low $\mathrm{pH}$ found in antenatal patients. The higher $\mathrm{pH}$ encountered in the family planning clinic may be due to the proportionally high number of postpartum patients, who were sent there as a part of normal routine after delivery, so occult vaginal bleeding and breastfeeding could be explanatory factors. In women attending fertility clinics however, the finding of increased $\mathrm{pH}$ and $\mathrm{AVF} / \mathrm{BV}$ could be worrisome. Implantation of the fertilised egg is less efficient in women with AVF [30], $\mathrm{BV}$ [31-33] and AV [34], and the presence of these abnormalities can be a sign of genital infections leading to cervicitis, endometritis or tubal damage [35]. Hence, we would strongly recommend routine vaginal $\mathrm{pH}$ testing of infertile women in Africa, followed by further genital testing if the $\mathrm{pH}$ is increased.

To be used as a general screening tool for high-risk conditions of the vagina, $\mathrm{pH}$ screening by self-assessment of $\mathrm{pH}$ of 4.5 or more would detect $90 \%$ of at-risk women, is cheap and easy to perform, and well accepted by Ugandan women. Furthermore, besides BV, around $40 \%$ of other pathologies, such as AV, would be discovered in these women with AVF. Given the high prevalence of AVF conditions in these Uganda women, almost two-thirds of women would have to be further examined, unless one is willing to accept an inferior sensitivity of the screening by choosing higher $\mathrm{pH}$ cut-offs.

In conclusion, screening by self-testing for abnormal vaginal $\mathrm{pH}$ is a feasible option to detect high risk for AVF, BV and $\mathrm{AV}$ in Ugandan women. It is acceptable, cheap and efficient, although due to the high prevalence of AVF, more than half of all women would need more testing, in order to maintain good sensitivity of the screening test. Women with HIV or consulting for infertility require extra attention for vaginal flora abnormalities and should be tested routinely for it.

Author contributions GD, JL, JB and AG participated in the design of the study.

FD, TM, NE and AG conceived the study, participated in its design and coordination, and helped to draft the manuscript.

$\mathrm{CM}, \mathrm{GD}$ and GB performed the microscopic examinations and helped to draft the manuscript.

All authors read and approved the final manuscript.

\section{Compliance with ethical standards}

Funding Femicare, a non-profit organisation based in Tienen, Belgium, supporting clinical research for women.

Conflict of interest None of the authors declares any conflict of interest.

Ethical approval The study was approved by the ethical committee of the Kampala University Hospital in November 2008.

Informed consent Written informed consent was signed by all patients before engaging in the study.

\section{References}

1. Mania-Pramanik J, Kerkar SC, Mehta PB, Potdar S, Salvi VS (2008) Use of vaginal pH in diagnosis of infections and its association with reproductive manifestations. J Clin Lab Anal 22(5):375379

2. Donders GG, Marconi C, Bellen G (2010) Easiness of use and validity testing of VS-SENSE device for detection of abnormal 
vaginal flora and bacterial vaginosis. Infect Dis Obstet Gynecol 2010:504972

3. Rossi A, Rossi T, Bertini M, Caccia G (2010) The use of Lactobacillus rhamnosus in the therapy of bacterial vaginosis. Evaluation of clinical efficacy in a population of 40 women treated for 24 months. Arch Gynecol Obstet 281(6):1065-1069

4. Sobel JD, Nyirjesy P, Kessary H, Ferris DG (2009) Use of the VSsense swab in diagnosing vulvovaginitis. J Womens Health (Larchmt) 18(9):1467-1470

5. Donders G, De Wet HG, Hooft P, Desmyter J (1993) Lactobacilli in Papanicolaou smears, genital infections, and pregnancy. Am J Perinatol 10(5):358-361

6. Hoyme UB, Saling E (2004) Efficient prematurity prevention is possible by $\mathrm{pH}$-self measurement and immediate therapy of threatening ascending infection. Eur J Obstet Gynecol Reprod Biol 115(2):148-153

7. Donders GG (2007) Definition and classification of abnormal vaginal flora. Best Pract Res Clin Obstet Gynaecol 21(3):355-373

8. Donders GG, Vereecken A, Bosmans E, Dekeersmaecker A, Salembier G, Spitz B (2002) Definition of a type of abnormal vaginal flora that is distinct from bacterial vaginosis: aerobic vaginitis. BJOG 109(1):34-43

9. Joesoef MR, Schmid G (2005) Bacterial vaginosis. Clin Evid 13: 1968-1978

10. Ness RB, Hillier S, Richter HE, Soper DE, Stamm C, Bass DC et al (2003) Can known risk factors explain racial differences in the occurrence of bacterial vaginosis? J Natl Med Assoc 95(3):201-212

11. Koumans EH, Sternberg M, Bruce C, McQuillan G, Kendrick J, Sutton $M$ et al (2007) The prevalence of bacterial vaginosis in the United States, 2001-2004; associations with symptoms, sexual behaviors, and reproductive health. Sex Transm Dis 34(11):864-869

12. Sewankambo N, Gray RH, Wawer MJ, Paxton L, McNaim D, Wabwire-Mangen F et al (1997) HIV-1 infection associated with abnormal vaginal flora morphology and bacterial vaginosis. Lancet 350(9077):546-550

13. Donders GG, Andabati G, Donders F, Michiels T, Eggermont N, Bellen G et al (2012) Acceptance of self-testing for increased vaginal $\mathrm{pH}$ in different subsets of Ugandan women. Int J STD AIDS 23(1):30-35

14. Donders GG, Caeyers T, Tydhof P, Riphagen I, van den Bosch T, Bellen G (2007) Comparison of two types of dipsticks to measure vaginal $\mathrm{pH}$ in clinical practice. Eur J Obstet Gynecol Reprod Biol 134(2):220-224

15. Larsson PG, Platz-Christensen JJ (1990) Enumeration of clue cells in rehydrated air-dried vaginal wet smears for the diagnosis of bacterial vaginosis. Obstet Gynecol 76(4):727-730

16. Nugent RP, Krohn MA, Hillier SL (1991) Reliability of diagnosing bacterial vaginosis is improved by a standardized method of gram stain interpretation. J Clin Microbiol 29(2):297-301

17. Donders GG (1999) Microscopy of the bacterial flora on fresh vaginal smears. Infect Dis Obstet Gynecol 7(4):177-179

18. Donders GG, Van Calsteren K, Bellen G, Reybrouck R, Van den Bosch T, Riphagen I et al (2009) Predictive value for preterm birth of abnormal vaginal flora, bacterial vaginosis and aerobic vaginitis during the first trimester of pregnancy. BJOG 116(10):1315-1324

19. Donders G, Bellen G, Rezeberga D (2011) Aerobic vaginitis in pregnancy. BJOG 118(10):1163-1170
20. Tansarli GS, Kostaras EK, Athanasiou S, Falagas ME (2013) Prevalence and treatment of aerobic vaginitis among nonpregnant women: evaluation of the evidence for an underestimated clinical entity. Eur J Clin Microbiol Infect Dis 32(8):977-984

21. Jahic M, Mulavdic M, Hadzimehmedovic A, Jahic E (2013) Association between aerobic vaginitis, bacterial vaginosis and squamous intraepithelial lesion of low grade. Med Arch 67(2): 94-96

22. Bologno R, Díaz YM, Giraudo MC, Fernández R, Menéndez V, Brizuela JC et al (2011) Importance of studying the balance of vaginal content (BAVACO) in the preventive control of sex workers. Rev Argent Microbiol 43(4):246-250

23. Marconi C, Donders GG, Martin LF, Ramos BR, Duarte MT, Parada CM et al (2012) Chlamydial infection in a high risk population: association with vaginal flora patterns. Arch Gynecol Obstet 285(4):1013-1018

24. Frey Tirri B (2011) Antimicrobial topical agents used in the vagina. Curr Probl Dermatol 40:36-47

25. Tempera G, Furneri PM (2010) Management of aerobic vaginitis. Gynecol Obstet Invest 70(4):244-249

26. Tempera G, Abbadessa G, Bonfiglio G, Cammarata E, Cianci A, Corsello S et al (2006) Topical kanamycin: an effective therapeutic option in aerobic vaginitis. J Chemother 18(4):409-414

27. Li J, McCormick J, Bocking A, Reid G (2012) Importance of vaginal microbes in reproductive health. Reprod Sci 19(3):235-242

28. Atashili J, Poole C, Ndumbe PM, Adimora AA, Smith JS (2008) Bacterial vaginosis and HIV acquisition: a meta-analysis of published studies. AIDS 22(12):1493-1501

29. Platz-Christensen JJ, Pernevi P, Hagmar B, Andersson E, Brandberg A, Wiqvist N (1993) A longitudinal follow-up of bacterial vaginosis during pregnancy. Acta Obstet Gynecol Scand 72(2):99-102

30. Spandorfer SD, Neuer A, Giraldo PC, Rosenwaks Z, Witkin SS (2001) Relationship of abnormal vaginal flora, proinflammatory cytokines and idiopathic infertility in women undergoing IVF. J Reprod Med 46(9):806-810

31. Eckert LO, Moore DE, Patton DL, Agnew KJ, Eschenbach DA (2003) Relationship of vaginal bacteria and inflammation with conception and early pregnancy loss following in-vitro fertilization. Infect Dis Obstet Gynecol 11(1):11-17

32. Liversedge NH, Turner A, Horner PJ, Keay SD, Jenkins JM, Hull MG (1999) The influence of bacterial vaginosis on in-vitro fertilization and embryo implantation during assisted reproduction treatment. Hum Reprod 14(9):2411-2415

33. Ralph SG, Rutherford AJ, Wilson JD (1999) Influence of bacterial vaginosis on conception and miscarriage in the first trimester: cohort study. BMJ 319(7204):220-223

34. Deb K, Chaturvedi MM, Jaiswal YK (2004) Comprehending the role of LPS in Gram-negative bacterial vaginosis: ogling into the causes of unfulfilled child-wish. Arch Gynecol Obstet 270(3):133146

35. Gaudoin M, Rekha P, Morris A, Lynch J, Acharya U (1999) Bacterial vaginosis and past chlamydial infection are strongly and independently associated with tubal infertility but do not affect in vitro fertilization success rates. Fertil Steril 72(4):730-732 